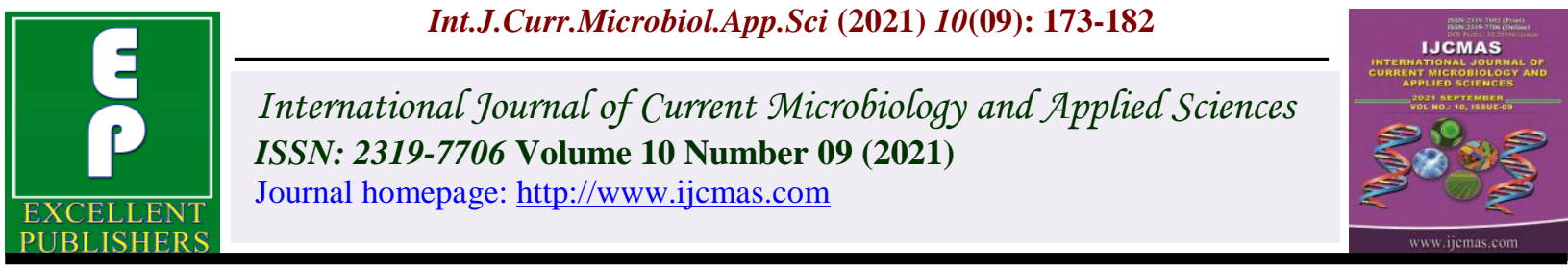

\title{
Identification of Effective Factors for Immobilized Lipase Catalysed Biodiesel Production from Pongamia pinnata Seed Oil Using Plackett-Burman Design
}

\author{
Shilpa K. Jigajinni* and Bharati S. Meti \\ Department of Biotechnology, Basaveshwar Engineering College(A), S Nijalingappa \\ Vidyanagar, Bagalkot 587102, Karnataka, India \\ *Corresponding author
}

\section{A B S T R A C T}

\section{Keywords}

Immobilized lipase, $\mathrm{PB}$ design, $\mathrm{pH}$, Fatty acid methyl ester, Pongamia seed oil

\section{Article Info}

\section{Accepted:}

10 August 2021

Available Online:

10 September 2021
Biodiesel a fatty acid alkyl esteris one of the promising biofuel and a clean energy source as an alternative to petroleum-based diesel fuels. The Enzymatic transesterification reaction is influenced by many factors such as amount of biocatalyst, molar ratio of oil to alcohol, temperature, $\mathrm{pH}$, rpm, time etc. Effective variables for transesterification may vary based on the type of feedstock and catalyst used, therefore it is essential to optimise the process suitable for each type of feedstock to achieve higher yield of biodiesel. The statistically-based Plackett-Burman experimental design was adopted in this study to identify effective factors for transesterification reaction of Pongamia pinnata seed oil using immobilized lipase. The factors used in the present study for Plackett-Burman design are molar ratio, amount of immobilized lipase, temperature, time, $\mathrm{pH}$, agitation and water content. The result showed that among seven variables, $\mathrm{pH}$ (p-value0.003), agitation speed(p-value 0.024 ) and amount of immobilized lipase(p-value 0.041) having $p<0.05$ are statistically significant, positively affecting the transesterification process of Pongamia seed oil. Further the variables which had significant effect on transesterification process will be selected for Response Surface Methodology studies to enhance the yield of biodiesel will be the future scope of work.

\section{Introduction}

Energy is important aspect for economic development of nation. Most amount of energy need is fulfilled from fossil resources. Increasing population and demand of energy has imparts more burden on available fossil sources (Tripathi et al., 2014). Currently world is facing scarcity of fossil fuels and large scale burning of fossil fuels leads to major environmental changes (Thangaraj et al., 2018). The need to find alternate for fossil fuels, take turn to renewable energy sources which are more ecofriendly produced from biomass and can replace the existing energy sources. One of such renewable energy source 
is Biodiesel. Biodiesel is a mixture of Fatty Acid Methyl Esters (FAMEs) which is produced from renewable resources such as vegetable oils by transesterification process in presence of chemical catalyst or biocatalyst. Use of biocatalyst is more advantageous than chemical catalyst. Biocatalyst used for biodiesel synthesis is lipase which is produced from plants, animals and microbes. To abate the issues related to chemical catalyst the use of biocatalyst was encouraged. Due to the high stability of enzymes as well as their convenient production, they are the best biocatalysts for producing biodiesel (Helal et al., 2021). Biodiesel has shown its ability to meet the energy demand of the world. Yearly consumption of diesel in India is approximately 40 million tons annually which constitute about $40 \%$ of the total petro products consumption hence biodiesel is one of promising fuel which has ability to meet the demand of transport fuel (Gangadhara and Prasad., 2016). The crude vegetable oil and animal fat can be made suitable to use as substitute fuel in diesel engines by four different routes like direct use or blending of oils, micro emulsion, pyrolysis and transesterification reaction. Among these methods transesterification method is most preferred route used to produce biodiesel using wide range of oils; by this method quality fuel can be produced. Vegetable oils like edible oils and non edible oils, animal fat and waste cooking oils are known to be used as feedstock's for biodiesel production across the world. More than 350 oil-bearing crops have been recognized as potential sources for biodiesel production. Among them only palm, jatropha, rapeseed, soybean, sunflower, cottonseed, safflower, and peanut oils are considered as viable feedstock's for commercial production of biodiesel [Al Zuhair, 2007]. Major non-edible plants like jatropha, karanja, polanga, neem, rubber, and mahua have shown significant potential as biodiesel feedstock (AKMA Islam et al.,
2018). Karanja oil emits less amount of harmful substances and inexpensive as compared to jatropha oil (Karmee et al., 2020 \& DewiHarreh et al., 2018). Currently non edible oils are used as the major source for biodiesel production as edible oils are costlier and these are used as source of food that may raise food verses fuel conflicts and has led to increase in price of the commodity due to its high consumption as food. Hence, the pursuit alternative to edible oil for biodiesel production has given rise to use of non-edible oils. It has been recognized as more sustainable and promising biodiesel feedstock when compared to edible oils (Vashistand Ahmad, 2012)

Enzymatic catalysis specifically produces high purity fatty acid alkyl esters under mild reaction conditions with yields of around $90 \%$. The enzymatic process is therefore a sustainable biotechnological alternative to chemical catalysis (Devanesan et al., 2007; Mamoru et al., 2001; Oznur and Melek, 2002). Recently, the development of enzymatic method of transesterification for industrial scale has been commercialized and is increasing significantly because of the merits of this process. Thus enzymes are an interesting prospect for industrial-scale production for reduction of production costs, as in this method uses wide variety of feeds such as high FFA oil, non-edible oils and spent oils, that reduces overall cost of process because major part of economy of biodiesel industry depends on cost of feedstock's (Kumari et al., 2007; Fjerbaek et al., 2009). The yield of biodiesel depends on the type of feedstock used and reaction parameters hence it is necessary to optimize the reaction conditions for each type of feedstock's. Factors affecting transesterification reaction involves concentration of catalyst, type of alcohol, molar ratio, temperature, $\mathrm{pH}$, agitation speed and time (Marchetti et al., 2007). Extensive research work has been done 
on use of non-edible oils for transesterification; however, there is no significant work has been carried out on the optimization of transesterification process, oil characterization and fuel analysis of most of the non-edible seed oils. Hence there is greater need of optimization of transesterification process to enhance the yield and analysis of biodiesel from non-edible oil sources. Optimization of transesterification of nonedible oils to identify the optimum conditions of reaction parameters suitable for type of feedstocks and catalyst used to obtain higher yield.

Statistical optimization is more advantageous than traditional method. Optimization of parameters of reaction systems will reduce the cost of the production of biodiesel and will make enzymatic transesterification for biodiesel production more promising. The Plackett-Burman (PB) design can be used in preliminary studies for the detection of influential factors on the experimental response and application of response surface methodology to further optimize the effective factors, that dramatically improves the yield of biofuels (Costarrosa et al., 2018; Milano et al., 2018; Dharma et al., 2016; Thirugnanasambandham et al., 2016) Manojkumar, Muthukumaran and. Sharmila, 2020) Plackett-Burman design is an efficient method that can be used for the screening of different variables for further optimization (Mehta et al., 2019). Plackett-Burman design gives information about the effect of single factor on response, i.e., percent biodiesel yield (Haq, Adeel, et al., 2020). The PlackettBurman is a statistical method where $n$ variables are studied in $n+1$ experimental runs. The advantage of this design is reduced time, consumables and human resources, hence it proves to be an excellent screening method to test different variables at a time (Premjyoti and Bharati, 2018). Therefore, the present study aims at identification of effective factors for transesterification of Pongamia seed oil using immobilized lipase with application of Plackett-Burman design.

\section{Materials and Methods}

\section{Lipase Production by Submerged Fermentation}

Lysinibacillus macroides FS1 was previously isolated from oil rich temple soil and identified using 16Sr DNA. The isolates were sub cultured routinely in the minimal media composed of $0.3 \%$ of yeast extract $0.5 \% \mathrm{NaCl}$, $0.5 \%$ peptone, $2 \%$ agar at $\mathrm{pH} 7$ and preserved in agar slants at $4{ }^{\circ} \mathrm{C}$ in the refrigerator (Sirisha et al.,2010). The lipase producing Lysinibacillus macroides FS1was grown in optimized medium containing: $3 \mathrm{gm}$ beef extract, $3 \mathrm{gm}$ galactose, $3 \mathrm{gm}$ ammonium chloride, $0.01 \mathrm{gm} \quad \mathrm{CaSO}_{4}, 0.05 \mathrm{gm} \quad \mathrm{KH}_{2} \mathrm{PO}_{4}$, $0.01 \mathrm{gm} \mathrm{MgSO}_{4} .7 \mathrm{H}_{2} \mathrm{O}, 1 \mathrm{gm}$ honge oil in $100 \mathrm{ml}$ distilled water and $\mathrm{pH}$ set to 7 . The flask were incubated at $37^{\circ} \mathrm{C}$ for $48 \mathrm{hr}$ at $120 \mathrm{rpm}$. The sample were collected after $48 \mathrm{hr}$ of incubation and centrifuged at 10000rpm for $30 \mathrm{~min}$ at $4^{\circ} \mathrm{C}$ to collect supernatant as crude lipase source for lipase immobilization (Bharathi et al., 2018, Babatunde and Sulaimon, 2017).

\section{Lipase Assay}

Lipase activity of free and immobilized lipase was measured by Titrimetric method using olive oil as substrate. $1 \mathrm{~g}$ of immobilized beads were added to reaction mixture containing $2 \mathrm{ml}$ of $0.05 \mathrm{M}$ phosphate buffer of $\mathrm{pH} 7.0$ and $1 \mathrm{ml}$ of olive oil, incubated at $37^{\circ} \mathrm{C}$ for $60 \mathrm{~min}$. The reaction was stopped by adding $1 \mathrm{ml}$ of acetone: ethanol solution in 1:1 ratio. The amount of fatty acids was estimated by titrating with $0.05 \mathrm{M} \mathrm{NaOH}$ in presence of phenolphthalein as an indicator until $\mathrm{pH} 10.5$. Amount of $\mathrm{NaOH}$ consumed indicates the amount of fatty acids liberated. One unit of enzyme activity is defined as the amount of enzyme required to liberate $1 \mu \mathrm{mol}$ of 
equivalent fatty acid (Patel et al., 2018). Lipase activity was calculated by using following Eq.1

Lipase Activity $\left(\frac{\mathrm{U}}{\mathrm{ml}}\right)$

$=\frac{\text { Vol of alkali consumed XStrength of alkali } x 1000}{\text { Vol of sample } x \text { Time in min }}$ ...Eq.1

Immobilization of Lipase

Immobilization of produced lipase was carried out by entrapment method using sodium alginate and calcium chloride. Sodium alginate of $4 \%$ were prepared by adding to $0.05 \mathrm{M}$ TrisHCl buffer ( $\mathrm{pH} 7)$ and boiled for $5 \mathrm{~min}$ to form uniform slurry, then cooled. The crude lipase was mixed with sodium alginate in equal proportion $(1: 1)$ by continuous stirring to obtain homogenous suspension. The lipase-alginate mixture was added drop wise to cold $\mathrm{CaCl}_{2}$ solution $(200 \mathrm{mM})$ using a hypodermic syringe. The obtained beads of $3 \mathrm{~mm}$ size were preserved for curing at $4{ }^{\circ} \mathrm{Cfor}$ $1 \mathrm{hr}$ (Adetunji and Olaniran, 2018).After curing beads were collected from the solution by filtration and then washed with cold Tris$\mathrm{HCl}$ buffer (0.05 M, pH 7) and distilled water to remove unbound lipase. These beads were stored in distilled water at $4^{\circ} \mathrm{C}$ till further use.

\section{Plackett-Burman Design}

Plackett-Burman design is very useful to identify the effective factors. PB experimental design is based on the first-order model, and this model describes no interaction among factors. This design was used in this study to analyse the effective parameters for transesterification using MINITAB 14 software. Seven variables were selected viz., molar ratio, amount of immobilized lipase, temperature, time, $\mathrm{pH}$, agitation speed and water content (Table 1). Each variable had two levels: low level (-) and high level(+). Higher concentration and lower concentrations of each variable was selected based on the literature. Total 12 experimental set ups were prepared each in $100 \mathrm{ml}$ conical flask with constant amount of Pongamia oil and performed the transesterification in shaking incubator at variable conditions and biodiesel yield as response were determined. The layout of Plackett Burman is shown in Table 2.

\section{Enzymatic Transesterification}

Biodiesel production proceeded using the process variables as per Table 2.Transesterification reaction was carried out in a $100 \mathrm{ml}$ conical flask in shaking incubator as previously described (Fig. 2). Briefly, immobilized lipase was added to $25 \mathrm{gm}$ of Pongamia oil and the mixture was supplemented with methanol and $\mathrm{pH}$ was adjusted with phosphate buffers. After completion of process, reaction mixture filtered to remove immobilized beads, collected filtrate were added to separating funnel and left overnight for separation of biodiesel and glycerol (Vallari et al., 2015). Following separation, two layers were formed: the upper layer being the biodiesel product while glycerol settled at the bottom layer of the separating funnel. Upper layer of biodiesel were used to calculate the yield.

\section{Biodiesel Yield}

The biodiesel yield $(\% \mathrm{wt})$, relative to the amount of experimental oil used was calculated by comparing the weight of the upper layer biodiesel to the weight of the crude oil used as described in Eq. 2.(Kareem et al., 2020)

$$
\begin{aligned}
& \text { Biodiesel yield } \mathrm{Y}(\%) \\
& =\frac{\text { Weight of the biodiesel produced }}{\text { Weight of crude oil used }} \times 100
\end{aligned}
$$

\section{Results and Discussion}

\section{Lipase Production and Activity Assay}

Production of lipase from Lysinibacillus 
macroides FS1 were carried in optimized medium as submerged fermentation process mentioned in methodology.The Media optimization was performed in previous studies and formulated optimised media for enhanced lipase activity. The production of enzymes at industrial scale mainly uses the submerged fermentation ( $\mathrm{SmF})$ technology, as this method of fermentation process easy to monitor and to control (Melani et al., 2019).

The use of submerged fermentation for lipase production using bacterial sp. gives satisfactory results studied by Vishwanatha et al., 2019. Culture supernatant were collected and lipase activity of $14.1 \mathrm{U} / \mathrm{ml}$ was assayed by titrimetric method as this is simplest method mentioned by Patel et al., 2018 and Sirisha et al., 2010.

\section{Immobilization of lipase}

Immobilized lipase offers many advantages over free lipase in terms of reusability, operational stability and cost effective process. Entrapment is one of immobilization techniques in which enzymes are physically restricted within a confined space or network.

Immobilization by using $\mathrm{Ca}$-alginate provides many benefits like its cost-effective process and environmentally friendly nature as per Qamar et al., 2020 and the concentrations of alginate and calcium chloride formed a key factor for enzyme immobilization since cross linking between alginate and calcium chloride results in gelation (Adetunji and Olaniran, 2018). Previous optimization studies revealed that $4 \%$ sodium alginate and $200 \mathrm{mM} \mathrm{CaCl}_{2}$ has higher immobilization efficiency, therefore in the present study $4 \%$ sodium alginate and $200 \mathrm{mM} \mathrm{CaCl}_{2}$ were used to prepare immobilized beads of lipase. This combination of sodium alginate and calcium chloride was suitable for formation of beads which are physically stable and active in reaction mixture. Produced lipase was successfully immobilized and beads are formed of round shape with $3 \mathrm{~mm}$ size as shown in Fig 1.

\section{Plackett-Burman Design Analysis}

The experimental design analysis was done using MINITAB-14 software. To test the significance of the hypothesis $\mathrm{p}$-value was used. If the p-value was less than 0.05, indicates the significance of the chosen variable and greater value indicates non significance of the hypothesis. The PB design matrix consists of 12 experimental runs, and the corresponding response namely biodiesel yield $(\%)$ is shown in table 2 .

The PB design was analysed by ANOVA analysis, and the estimated effects and coefficient of process variables are shown in table $3 . R^{2}$ value $94.99 \%$ indicates the model is significant and the results obtained by ANOVA (Table 4) revealed that the main effects of the factors in the model term were highly significant ( $p$-value0.018). From the results, it is found that among the seven variables tested, molar ratio, amount of immobilised lipase, reaction time, $\mathrm{pH}$ and agitation speed exhibited positive effect, whereas the other variables, that is, temperature and water content exerted negative effects on biodiesel yield. Among the positive variables $\mathrm{pH}(\mathrm{p}$ value 0.003$)$, agitation speed ( $p$ value 0.024)and amount of immobilized lipase( $\mathrm{p}$ value 0.041$)$ had significant effect as the p-values are less than 0.05 , indicating highest effect on biodiesel yield(Table 3). Hence further evaluation of these variables is required to enhance the yield of biodiesel from Pongamia seed oil. 
Table.1 Process Variables for Plackett-Burman Design

\begin{tabular}{|c|c|c|}
\hline \multirow{2}{*}{ Process Variables } & \multicolumn{2}{|c|}{ Levels } \\
\cline { 2 - 3 } & Low (-) & High (+) \\
\hline Molar ratio & $1: 3$ & $1: 15$ \\
\hline Amount of Immobilized Lipase (\%) & 5 & 20 \\
\hline Temperature $\left({ }^{\circ} \mathbf{C}\right)$ & 25 & 45 \\
\hline Time (hr) & 2 & 24 \\
\hline pH & 6 & 8 \\
\hline Agitation speed (rpm) & 50 & 200 \\
\hline Water content $(\mathbf{\%})$ & 1 & 20 \\
\hline
\end{tabular}

Table.2 Seven variables with twelve runs of two level Plackett-Burman Design

\begin{tabular}{|c|c|c|c|c|c|c|c|c|}
\hline Run & $\begin{array}{c}\text { Molar } \\
\text { ratio }\end{array}$ & $\begin{array}{c}\text { Amount of } \\
\text { Immobilized } \\
\text { Lipase }(\mathbf{\%})\end{array}$ & $\begin{array}{c}\text { Temperature } \\
\mathbf{(} \mathbf{C})\end{array}$ & $\begin{array}{c}\text { Time } \\
\mathbf{( h r})\end{array}$ & $\mathbf{p H}$ & $\begin{array}{c}\text { Agitation } \\
\text { speed } \\
(\mathbf{r p m})\end{array}$ & $\begin{array}{c}\text { Water } \\
\text { content } \\
(\mathbf{\%})\end{array}$ & $\begin{array}{c}\text { Yield of } \\
\text { Biodiesel } \\
(\mathbf{\%})\end{array}$ \\
\hline $\mathbf{1}$ & $1: 15$ & 5 & 45 & 2 & 6 & 50 & 20 & 9.7 \\
\hline $\mathbf{2}$ & $1: 3$ & 20 & 45 & 24 & 6 & 200 & 20 & 18.8 \\
\hline $\mathbf{3}$ & $1: 3$ & 5 & 25 & 2 & 6 & 50 & 1 & 9.3 \\
\hline $\mathbf{4}$ & $1: 15$ & 20 & 25 & 24 & 8 & 50 & 20 & 24.4 \\
\hline $\mathbf{5}$ & $1: 3$ & 20 & 25 & 2 & 6 & 200 & 20 & 12.2 \\
\hline $\mathbf{6}$ & $\mathbf{1 : 1 5}$ & $\mathbf{2 0}$ & $\mathbf{4 5}$ & $\mathbf{2}$ & $\mathbf{8}$ & $\mathbf{2 0 0}$ & $\mathbf{1}$ & $\mathbf{2 8 . 7}$ \\
\hline $\mathbf{7}$ & $1: 3$ & 20 & 45 & 2 & 8 & 50 & 1 & 18.8 \\
\hline $\mathbf{8}$ & $1: 15$ & 5 & 25 & 2 & 8 & 200 & 20 & 21 \\
\hline $\mathbf{9}$ & $1: 15$ & 20 & 25 & 24 & 6 & 50 & 1 & 17 \\
\hline $\mathbf{1 0}$ & $1: 3$ & 5 & 45 & 24 & 8 & 50 & 20 & 15.5 \\
\hline $\mathbf{1 1}$ & $1: 3$ & 5 & 25 & 24 & 8 & 200 & 1 & 24.8 \\
\hline $\mathbf{1 2}$ & $1: 15$ & 5 & 45 & 24 & 6 & 200 & 1 & 16.6 \\
\hline
\end{tabular}

Table.3 The Estimated effects and coefficients for biodiesel yield response of Plackett-Burman Design

\begin{tabular}{|c|c|c|c|c|c|}
\hline Variable & Effect & Co-efficient & SE Coefficient & t-value & p-value \\
\hline Constant & & 18.681 & 0.7533 & 24.80 & 0.000 \\
\hline Molar ratio & 3.000 & 1.500 & 0.6457 & 2.32 & 0.081 \\
\hline Amount of lipase & 5.111 & 2.556 & 0.8609 & 2.97 & 0.041 \\
\hline Temperature & -0.150 & -0.075 & 0.9686 & -0.08 & 0.942 \\
\hline Reaction time & 2.900 & 1.450 & 0.6457 & 2.25 & 0.088 \\
\hline pH & 8.267 & 4.133 & 0.6457 & 6.40 & 0.003 \\
\hline Agitation Speed & 4.567 & 2.283 & 0.6457 & 3.54 & 0.024 \\
\hline Water content & -2.267 & -1.133 & 0.6457 & -1.76 & 0.154 \\
\hline
\end{tabular}

$\mathrm{S}=2.23681 \quad \mathrm{R}-\mathrm{Sq}=94.99 \% \quad \mathrm{R}-\mathrm{Sq}(\operatorname{adj})=86.22 \%$ 
Table.4 Analysis of Variance (ANOVA) for Biodiesel yield response

\begin{tabular}{|c|c|c|c|c|c|c|}
\hline Source & DF & Seq SS & Adj SS & Adj MS & F & P \\
\hline Main Effects & 7 & 379.33 & 379.33 & 54.190 & 10.83 & 0.018 \\
\hline Residual Error & 4 & 20.01 & 20.01 & 5.003 & & \\
\hline Total & 11 & 399.35 & & & & \\
\hline
\end{tabular}

Fig.1 Immobilized beads of lipase from Lysinibacillus macroides FS1

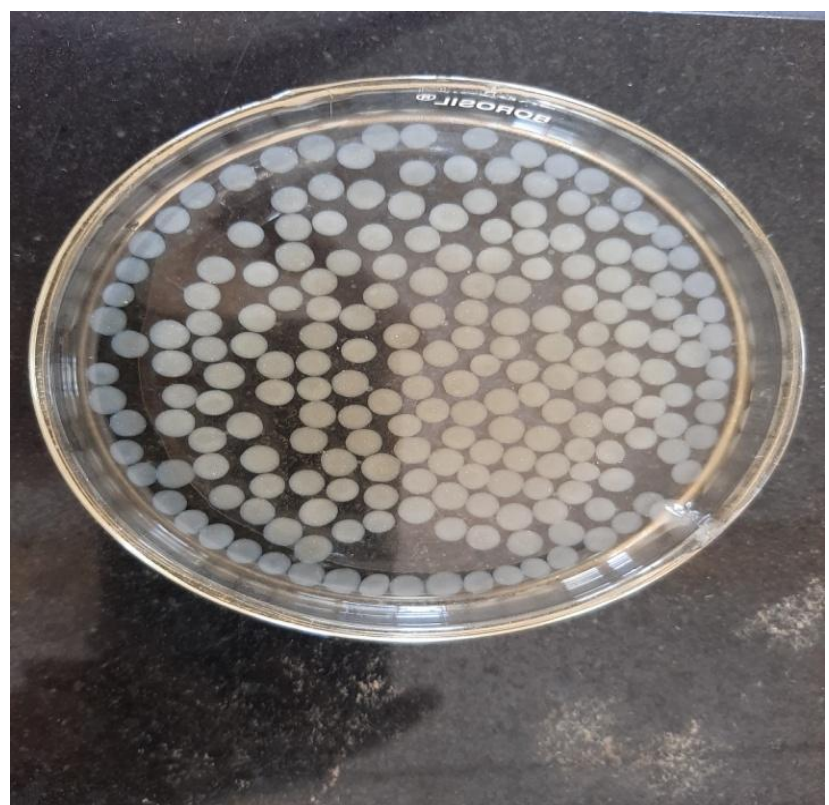

Fig.2 Experimental Setups of Plackett-Burman Design

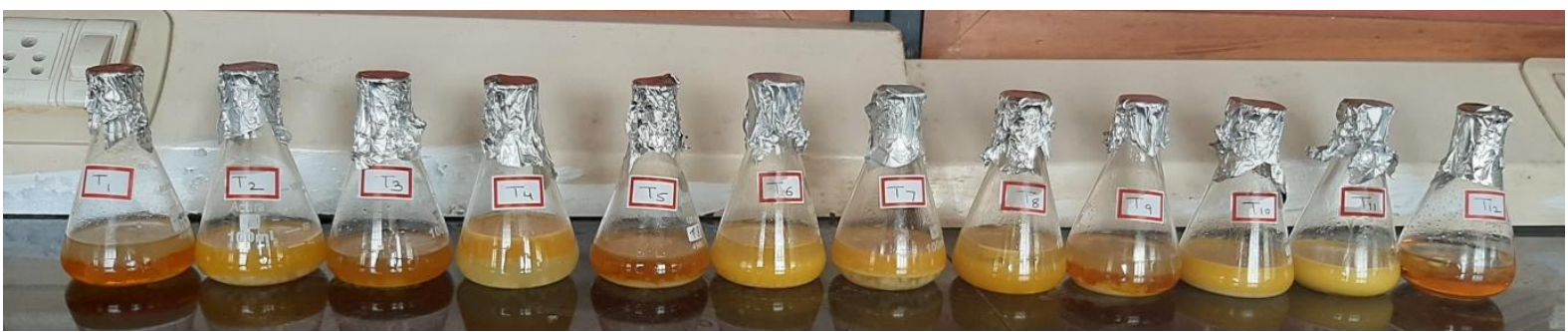

As per literature, the temperature is one of the important factor affects transesterification reaction but in the present study temperature had shown negative effect may be due to the immobilization of lipase that has shown stability to change in temperature so there is not much effect on yield when temperature is altered in the range of 25 to $45^{\circ} \mathrm{C}$ similarly reported by K. Thirugnanasambandham, 2018. But $\mathrm{pH}$ had a highest effect among seven variables. This clearly indicates that enzymatic transesterification process is more sensitive to $\mathrm{pH}$ as enzyme activity affected by $\mathrm{pH}$ hence further $\mathrm{pH}$ need to be properly evaluated for biodiesel synthesis. Along with the $\mathrm{pH}$ next highest effect was shown by agitation speed because agitation of oil and catalyst mixture enhances the reaction. And amount of immobilized lipase also had greater effect, as concentration of biocatalyst is one of the key factor for yield of biodiesel. As higher amount of immobilized beads will yield more 
biodiesel but up to certain limit beyond that it will not affect as all substrates are saturated.

By putting each component at different levels in each combination, biodiesel yield achieved was $28.7 \%$ (Table 2 and Run No. 6). The results of $\mathrm{PB}$ design clearly indicates that the model is highly significant. Hence, based on the data obtained from $\mathrm{PB}$ design, $\mathrm{pH}$, agitation speed and amount of immobilized lipase were chosen for further optimization study by using BBD of RSM.

In the present study, immobilized lipase from Lysinibacillus macroides FS1were prepared using calcium alginate as support material via entrapment method. The produced immobilized lipase was used as biocatalyst for biodiesel synthesis. The identification of effective factors was performed using statistical design of experiments, offers efficient methodology to identify the significant variables. The most significant factors for biodiesel production from Pongamia seed oil using immobilized lipase were identified by Plackett- Burman design are $\mathrm{pH}$, agitation speed and amount of immobilized lipase. These significant factors identified were considered for further optimization by BBD using response surface methodology.

\section{Acknowledgment}

We thank Department of Biotechnology Basaveshwar Engineering College(A), Bagalkot for providing facilities to carry out experiments.

\section{References}

Abul Kalam Mohammad Aminul Islam, Sri Rizki Putri Primandari and Zahira Yaakob.2018. Non-Edible Vegetable Oils as Renewable Resources for Biodiesel Production: South-East Asia Perspective. Advances in Biofuels \& Bioenergy.DOI: 10.5772/intechopen.73304.

Adetunji, A. I \& Olaniran, A. O. 2018. Immobilization and characterization of lipase from an indigenous Bacillus aryabhattai SE3-PB isolated from lipidrich wastewater. Preparative Biochemistry and Biotechnology.48(10): 898-905.

Akshita, M., Roji, S., and Reena, G.2019. Statistical Optimization by Response Surface Methodology to Enhance Lipase Production Aspergillus fumigatus. The Open Microbiology Journal. 13, 86-93.

Al-Zuhair S. 2005. Production of biodiesel by lipase catalysed transesterification of vegetable oil. Kinetic study. BiotechnolProg. 21, 1442-1448.

AndZongpei Babatunde, A. and Sulaimon, A. 2017. Optimization and Lipase Production of Lysinibacillus sphaericus in Domestic Oil Rich Waste Water. Biotechnology Journal International.19(4):1-12.

Bharathi, D., Rajalakshmi, G., Komathi, S. 2018.Optimization and production of lipase enzyme from bacterial strains isolated from petrol spilled soil. Journal of king saud university-science. 31(4):898901.

Costarrosa, L., Leiva-Candia, D., CuberoAtienza, A., Ruiz, J. \& Dorado, M. 2018. Optimization of the Transesterification of Waste Cooking Oil with Mg-Al Hydrotalcite Using Response Surface Methodology. Energies. 11 (2): 302. http:// www.mdpi.com/1996-1073/11/2/302

Devanesan, M. G., Viruthagiri, T. and Sugumar, N. 2007. Transesterification of Jatropha oil using immobilized Pseudomonas fluorescens. African journal of Biotechnology.6(21): 2497-2501.

Dewi Harreh, Saleh, A. A., Reddy, A. N. R. and Hamdan, S. 2018. An Experimental Investigation of Karanja Biodiesel Production in Sarawak, Malaysia. Hindawi Journal of Engineering.1-8. https://doi.org/10.1155/2018/4174205.

Dharma, S., Masjuki, H. H., Ong, H. C., Sebayang, A. H., Silitonga, A. S., F. Kusumo, F., \& Mahlia, T. M. I. 2016. Optimization of biodiesel production 
process for mixed JatrophacurcasCeibapentandra biodiesel using response surface methodology. Energy Conversion and Management. 115,178-190. https://doi.org/10.1016/j.enconman.2016.0 2.034 .

Fjerbaek, L., Knud, V., Christensen, and Birgir Norddahl. 2009. A Review of the Current State of Biodiesel Production Using Enzymatic Transesterification. Biotechnology and Bioengineering, 102(5): 1298-1315.

Gangadhara, R. and Prasad, N. 2016. Studies on optimization of transesterification of certain oils to produce biodiesel. Chemistry International,2(2).

Haq, A., Adeel, S., Khan, A. et al., 2020.Screening of Lipase-Producing Bacteria and Optimization of LipaseMediated Biodiesel Production from Jatrophacurcas Seed Oil Using Whole Cell Approach. Bioenerg.Res. 13, 12801296. https://doi.org/10.1007/s12155-02010156-1

Helal, S. E., Abdelhady, H. M., Abou-Taleb, K. A., Hassan, M. G. and Ame. M. M. 2021. Lipase from Rhizopusoryzae R1: in-depth characterization, immobilization, and evaluation in biodiesel production. J Genet EngBiotechnol. 19(1):1-13.

Kareem, S. O., Falokun, E. I., Balogun, S. A., Oluwaseyi A. A. and Omeike, S. O. 2020. Improved biodiesel from palm oil using lipase immobilized calcium alginate and Irvingiaga bonensis matrices. BeniSuefUniv J Basic Appl Sci. 9(59):1-8.

Kumari, V., Shah, S. \& Gupta, M. N. 2007. Preparation of biodiesel by lipasecatalyzed transesterification of high free fatty acid containing oil from Madhucaindica. Energy Fuels. 21(1):368-372.

Mamoru, I S O., Baoxue, C., Masashi, E. 2001. Production of biodiesel fuel from triglycerides and alcohol using Immobilized lipase. J. Mol. Catal. 16: 5358.

Manojkumar, N., Muthukumaran, C., and Sharmila, G. 2020.A comprehensive review on the application of response surface methodology for optimization of biodiesel production using different oil sources. Journal of King Saud UniversityEngineering

Sciences..https://doi.org/10.1016/j.jksues.2 020.09.012.

Marchetti, J. M., Miguel, V. U. \& Errazu, A. F. 2007. Possible methods for biodiesel production. Renewable and Sustainable Energy Reviews.11, 1300-1311.

Melani, N. B., Tambourgi, E. B. and Silveira, E. 2019.Lipases: From Production to Applications. Separation \& Purification Reviews.00: 1-16.

Milano, J., Ong, H. C., Masjuki, H. H., Silitonga, A. S., Wei-Hsin Chen, F. Kusumo, F., Dharma, S., \& Sebayang, A. H. 2017. Optimization of biodiesel production by microwave irradiationassisted transesterification for waste cooking oil-Calophylluminophyllum oil via response surface methodology. Energy Conversion and Management.158, 400415.https://doi.org/10.1016/j.enconman..12 .027 .

Oznur, K., \& Melek, T. 2002. Immobilized Candida antarctica lipase catalyzed alcoholysis of cotton seed oil in a solvent free medium. Bioresour. Technol. 83: 125129.

Patel P., Desai, B. 2018. Isolation, identification and production of lipase producing bacteria from oil contaminated soil. BMR Microbiology. 4 (1): 1-7.

Premjyoti, C. P., and Bharati, S. M. 2018.Isolation of Microalgae for Biomass and Lipid Enhancement through PlackettBurmann Design. Int.J.Curr.Microbiol. App.Sci. 7(3): 2508-2518. doi: https://doi.org/10.20546/ijcmas.2018.703.2 90

Qamar, S. A., Asgher, M., Bilal, M. 2020. Immobilization of Alkaline Protease From Bacillus brevis Using Ca-Alginate Entrapment Strategy for Improved Catalytic Stability, Silver Recovery and Dehairing Potentialities. Catalysis Letters. 150:3572-3583.

Sirisha, E., Rajasekar and Lakshmi Narasu M. 
2010.Isolation and optimization of lipase producing bacteria from oil contaminated soils. Advances in Biological Research. 4(5):249-252.

Talekar, S. and Chavare, S. 2012. Optimization of immobilization of $\alpha$-amylase in alginate gel and its comparative biochemical studies with free $\alpha$-amylase. Recent Research in Science and Technology. 4(2): 01-05.

Thangaraj, B., Solomon, P. R., Bagavathi, M.,, Srinivasan, R. and Lin Lin. 2018. Catalysis in biodiesel production-a review. Clean Energy. Vol. XX, No. XX:1-22.

Thirugnanasambandham, K., Sivakumar, V., and Shine, K. 2016. Performance evaluation of chemical coagulation process to treat bagasse wastewater: modeling and optimization. Polish Journal of Chemical Technology. 18 (1): 99-104. https://doi.org/10.1515/pjct-2016-0015.

Tripathi, R., Singh, J., Bharti, R. K., Thakur, I. S. 2014. Isolation, purification and characterization of lipase from Microbacterium sp. and its application in biodiesel production. Energy Procedia.54:518-529.
Vallari, R., Chourasia, A. S., Gawas, A. S., Menon, P. M., Shinde.2015.Production of Biodiesel by Enzymatic Transesterification using Immobilized Lipase. International Journal of Engineering Research and General Science.3 (3):1238-1246.

Vashist, D., and Ahmad, M. 2012. Comparative Study of Performance and Emission Characteristics of a Diesel Engine Fueled by Castor and Jatropha Methyl Ester with the Help of $t$ Test. International Journal of Automotive Engineering. 2(2): 61-67.

Vishwanatha, T., Patil, S. J., Siddalingeshwar, K. G. and Hiremath, L. 2019.Isolation and Screening of Lipase Producing Microbes from Oil Contaminated Soil. Advances in Bioplastics.7-13.

Yücel, S., Terzioğlu, P. and Özçimen, D. 2012. Lipase Applications in biodiesel Production IntechOpen.

Zhang, S., Shang, W., Yang, X., Zhang, S., Zhang, X., Chen, J. 2013. Immobilization of Lipase Using Alginate Hydrogel Beads and Enzymatic Evaluation in Hydrolysis of p-Nitrophenol Butyrate. Bull. Korean Soc. 34:2741-2745.

\section{How to cite this article:}

Shilpa K. Jigajinni and Bharati S. Meti. 2021. Identification of Effective Factors for Immobilized Lipase Catalysed Biodiesel Production from Pongamia pinnata Seed Oil Using Plackett-Burman Design. Int.J.Curr.Microbiol.App.Sci. 10(09): 173-182.

doi: https://doi.org/10.20546/ijcmas.2021.1009.020 